\title{
DIVERSIDADE GENÉTICA DE CULTIVARES DE ALHO (Allium sativum L.) POR MEIO DE MARCADOR MOLECULAR RAPD ${ }^{1}$
}

\author{
Genetic diversity of the cultivars of garlic (Allium sativum L.) for molecular marker RAPD
}

\author{
José Hortêncio Mota ${ }^{2}$, Rovilson José de Souza ${ }^{3}$, Jony Eshi Yuri ${ }^{4}$, \\ Geraldo Milanez de Resende ${ }^{5}$, Luciano Vilela Paiva ${ }^{6}$
}

\section{RESUMO}

Realizou-se este estudo com o objetivo de determinar a diversidade genética entre doze cultivares de alho, por meio de marcadores moleculares RAPD. Foram utilizados seis cultivares nobres e seis cultivares seminobres. A análise de agrupamento das similaridades genéticas foi realizada pelo método UPGMA, gerando um dendrograma utilizando o índice de Jaccard. Houve a formação de dois grupos, sendo o primeiro grupo formado pelas cultivares nobres (Roxo Pérola de Caçador, Chonan, Contestado 12, Caçador 30, Caçador 40 e Quitéria 595), ou seja, cultivares que precisam de vernalização para a formação do bulbo, e um segundo formado pelas cultivares seminobres (Gigante Curitibanos, Gigante Roxo, Gigante Roxão, Gravatá, Amarante e Cateto Roxo) ou que não precisam de vernalização para a formação do bulbo. As cultivares nobres e seminobres apresentaram 57,1\% e $54,2 \%$ de similaridade, respectivamente. Pelos resultados, pode-se concluir que o marcador molecular RAPD foi eficiente em separar dois grupos de cultivares de Allium sativum.

Termos para indexação: Allium sativum, RAPD, cultivares, divergência genética.

\section{ABSTRACT}

The objective of this study was to determine the genetic diversity among twelve garlic cultivars, with RAPD molecular marker. Six cultivars noble and six cultivars half-noble were tested. The analysis of grouping by genetic similarities was carried out by the method of UPGMA with generated a dendrogram using the Jaccard index. Have the formation of two groups, being the first group formed by the cultivars noble (Roxo Pérola de Caçador, Chonan, Contestado 12, Caçador 30, Caçador 40 and Quitéria 595) those that need vernalization for the formation of the bulb and a second group formed by the cultivars half-noble (Gigante Curitibanos, Gigante Roxo, Gigante Roxão, Gravatá, Amarante and Cateto Roxo) which do not need vernalization for formation of the bulb. The cultivars noble and half-noble presented 57,1\% and 54,2\% of similarity, respectively. The results allowed to conclued that RAPD molecular marker were efficient in separating two groups of cultivars the Allium sativum.

Index terms: Allium sativum, RAPD, cultivars, genetic divergence.

(Recebido para publicação em 12 de maio de 2003 e aprovado em 26 de agosto de 2003)

\section{INTRODUÇÃO}

O alho, no Brasil, ocupa o quarto lugar em importância econômica entre as hortaliças, sendo superado apenas pelas culturas da batata, tomate e cebola (FILGUEIRA, 2000). No país, há uma grande quantidade de cultivares de alho e, segundo Souza et al. (1978), a maioria das cultivares de alho existentes surgiram por mutações somáticas e seleções de características desejáveis pelos agricultores.

O mercado brasileiro utiliza, comercialmente, dois grandes grupos: um denominado de alhos nobres e um segundo grupo conhecido como seminobres. Os alhos pertencentes ao grupo nobre possuem cabeça redonda, com bulbos uniformes e grandes, apresentando poucos bulbilhos. Os bulbos tem túnica branca e pelícu-

\footnotetext{
${ }^{1}$. Parte da tese de doutorado do primeiro autor. Bolsista do CNPq.

2. Engenheiro Agrônomo. Centro Universitário de Dourados - Departamento de Ciências Agrárias, Caixa Postal 533, 79804-970, Dourados, MS. hortenciomota@terra.com.br

3. Engenheiro Agrônomo. Departamento de Agricultura da Universidade Federal de Lavras/UFLA, Caixa Postal 37, 37200-000. Lavras, MG. rovilson@ufla.br

4. Engenheiro Agrônomo. REFRICON - Rod. Régis Bittencourt s/n, km 294, 06850-000, Itapecerica da Serra, SP. jonyyuri@uol.com.br

5. Engenheiro Agrônomo. Embrapa Semi-Árido, Caixa Postal 23, 56300-970, Petrolina, PE. gmilanez@cpatsa. embrapa.br

6. Engenheiro Agrônomo. Departamento de Química da UFLA. luciano@ufla.br
} 
la de cor rósea ou roxa, necessitando serem vernalizados para bulbificação e apresentando sensibilidade ao pseudoperfilhamento. Já o grupo seminobre caracterizase por possuírem alhos de cabeça irregular, com bulbos desuniformes e de túnica branca com película branca a levemente arroxeada, não necessitando de vernalização para a formação do bulbo. A separação entre e dentro dos grupos ocorre, na maioria das vezes, com base em características morfológicas da planta, e isso requer o plantio e certo período de tempo para que os fenótipos sejam manifestados.

Lima (2001) ressalta que uma das maiores dificuldades para a conservação e o manejo racional das espécies vegetais consiste na carência de informações sobre os níveis e a organização da variabilidade genética em populações naturais e bancos de germoplasma. Assim, a caracterização da variabilidade genética é uma das primeiras etapas para que se possa organizar um programa de conservação ou melhoramento de qualquer espécie vegetal.

No estudo da diversidade genética entre e dentro espécies vegetais, em especial as hortaliças, a utilização de marcadores moleculares para estudos da diversidade genética em espécies vegetais tem sido crescente nas últimas décadas (SAKIYAMA, 1993). Entre os marcadores moleculares, a técnica de RAPD apresenta vantagem sobre os demais marcadores, por ser de fácil utilização, requerer menor quantidade de DNA, gerar grande número de polimorfismo, ser de baixo custo e não ser influenciado por condições ambientais (FERREIRA e GRATTAPAGLIA, 1998).

Com o objetivo de gerar conhecimento sobre a variabilidade genética em Allium sativum L. cultivados no Brasil, realizou-se o presente estudo com doze cultivares de alho dos grupos nobre e seminobre por meio de marcador molecular RAPD.

\section{MATERIAL E MÉTODOS}

O estudo foi realizado no Laboratório de Biologia Molecular da EMBRAPA Milho e Sorgo, localizado em Sete Lagoas/MG. Foram utilizadas doze cultivares de alho, sendo seis classificadas como nobres e seis classificadas como seminobres.

As cultivares nobre utilizadas foram: Chonan, Roxo Pérola de Caçador, Caçador 30, Quitéria 595, Contestado 12, Caçador 40, todas provenientes do Estado de Santa Catarina. No grupo das seminobres, utilizaram-se as cultivares Gigante Roxo, Gigante Roxão, Amarante, Cateto Roxo e Gravatá, cultivadas em Minas Gerais. Outra cultivar seminobre utilizada foi a cultivar catarinense Gigante Curitibanos que, pelas características morfológicas, apresenta exigência climática semelhante às cultivares tradicionalmente plantadas em Minas Gerais, não necessitando de vernalização para plantio.

\section{Extração e quantificação do DNA genômico}

Para a extração do DNA de Allium sativum, foi utilizado o método de Saghai-Maroof modificado. Foram utilizados 2,5 $\mathrm{g}$ do bulbilho descascado in natura triturado em $\mathrm{N}_{2}$ líquido com a adição de PVP. Em seguida, o material foi transferido para um tubo de centrífuga juntamente com $10 \mathrm{~mL}$ de tampão de extração (1 M de Tris pH 7,5; 0,5 M EDTA pH 8,0; 5 M NaCl; $1 \%$ CTAB; 2\% $\quad \beta$-Mercaptoetanol) e incubado a $65^{\circ} \mathrm{C}$ em banho-maria por 60 minutos, sendo homogeneizado a cada 15 minutos. Em seguida, os tubos foram retirados e deixados esfriar à temperatura ambiente; sendo adicionados $10 \mathrm{~mL}$ da mistura clorofórmio:octanol (24:1) e homogeneizado por 10 minutos. A separação das fases orgânica e aquosa foi realizada por centrifugação a $3.000 \mathrm{rpm}$ por 10 minutos, sendo o sobrenadante transferido para outro tubo, e com a adição de $6 \mathrm{~mL}$ de isopropanol gelado $\left(-5^{\circ} \mathrm{C}\right)$, houve a precipitação dos ácidos nucléicos (DNA e RNA).

O precipitado foi removido com o auxílio de uma alça de vidro para outro tubo contendo 3 $\mathrm{mL}$ de TE $\mathrm{pH} 8,0(0,01 \mathrm{M}$ Tris $\mathrm{pH} 8,0 ; 0,001 \mathrm{M}$ de EDTA pH 8,0), onde permaneceu incubado à temperatura ambiente até sua completa solubilização. Em seguida, os ácidos nucléicos foram novamente precipitados pela adição de $3 \mathrm{~mL}$ de etanol absoluto gelado, e transferido para tubos de Eppendorf contendo $400 \mu \mathrm{L}$ de TE pH 8,0. A quantificação do DNA foi realizada em gel de agarose $1 \%$, por comparação com padrão de DNA de concentração conhecida.

A eletroforese dos produtos amplificados por RAPD foi realizada a $100 \mathrm{~V}$ em tampão TAE (1mM EDTA pH 8,0; $40 \mathrm{mM}$ Tris pH 8,0; $20 \mathrm{mM}$ de ácido acético) por 40 minutos e o gel posteriormente foi tratado com brometo de etídio (10\%) durante 20 minutos sob agitação, visualizado sob luz ultravioleta, sendo a imagem do gel captada pelo sistema de documentação "Eagle Eye" (Stratagene, La Jolla, CA, USA).

\section{Amplificação do DNA}

Cada reação de amplificação foi realizada em volume final de $25 \mu \mathrm{L}$ contendo $50 \mathrm{ng}$ de DNA; $2,5 \mu \mathrm{L}$ tampão PCR 10X; 2,5 mM dNPTS; 1 U de Taq DNA 
polimerase e $1 \mu \mathrm{L}$ primer $(4 \mu \mathrm{M})$. O processo de amplificação foi realizado em um termociclador GeneAmp PCR System, modelo 9600 (Applied Biosystem, Palo Alto, CA, USA).

A programação utilizada foi constituída por uma temperatura de desnaturação de $95^{\circ} \mathrm{C}$ por 2 minutos, seguido de 45 ciclos de amplificação composto por 3 etapas. A primeira fase foi a de desnaturação do DNA a $95^{\circ} \mathrm{C}$ por 1 minuto; a segunda fase promoveu o anelamento dos primers a $40^{\circ} \mathrm{C}$ por 1 minuto; e a terceira fase para a extensão e incorporação dos nucleotídeos a $72^{\circ} \mathrm{C}$ por 2 minutos. Após a realização dessas etapas, a amostra continuou no termociclador à temperatura de $72^{\circ} \mathrm{C}$ por 5 minutos.

Após o término do processo, foram colocados em cada amostra $4 \mu \mathrm{L}$ de corante $(50 \%$ de orange e $50 \%$ de xilene cianole), aplicados em gel de agarose a $1 \%$, e os fragmentos amplificados foram resolvidos por eletroforese a $100 \mathrm{~V}$. Após a eletroforese, o gel foi incubado em solução de brometo de etídio (10\%) durante 20 minutos sob agitação e, posteriormente, visualizado sob luz ultravioleta, sendo as imagens captadas pelo sistema de fotodocumentação "Eagle Eye" (Stragene, La Jolla, CA, USA).

\section{Análises dos produtos amplificados por RAPD}

Foram utilizados para o estudo 4 kits de Primers Operon (A, B, F e W), totalizando 80 primers. Os fragmentos de DNA amplificados foram computados pela presença (1) ou ausência de bandas (0). Foram utilizadas para análise somente as bandas polimórficas.

Com o objetivo de verificar o mínimo de marcadores polimórficos necessários para a estimativa da similaridade genética entre as cultivares, foi realizada análise entre a correlação e desvio-padrão utilizando o programa GQMOL (CRUZ, 1999), agrupando-se ao acaso os 20 marcadores polimórficos, acrescidos de 10 marcadores sucessivamente até a utilização de todos os marcadores polimórficos.

Os índices de similaridade possibilitam gerar a análise de agrupamentos UPGMA (Unweigth PairGroup Method Arithmetic Average) estabelecendo a relação entre as espécies. A similaridade genética entre as cultivares de alho foi calculada com o auxílio do software NTSYSpc 2,02 k (ROHLF, 1992).

Para a quantificação da similaridade genética, podem ser utilizados índices de similaridade, entre os quais destaca-se o índice de similaridade de Jaccard:

$$
S_{i j}=\frac{a}{(a+b+c)}
$$

Em que:

$\mathrm{a}=\mathrm{n}^{\mathrm{o}}$ bandas presentes nos genótipos i e j;

$\mathrm{b}=\mathrm{n}^{\mathrm{o}}$ bandas presentes nos genótipos $\mathrm{i}$;

$\mathrm{c}=\mathrm{n}^{\mathrm{o}}$ bandas presentes nos genótipos $\mathrm{j}$.

$\mathrm{O}$ erro associado $\left(\mathrm{S}_{\mathrm{Sij}}\right)$ a cada similaridade $\left(\mathrm{S}_{\mathrm{ij}}\right)$ foi estimado conforme sugerido por Skroch et al. (1992):

$$
S_{S_{i j}}=\sqrt{S_{i j} \times \frac{1-S_{i j}}{n-1}}
$$

Em que: $\mathrm{n}=\mathrm{n}^{\mathrm{o}}$ total de combinações $\mathrm{a}, \mathrm{b}$ e c para cada par de genótipos.

Os genótipos geneticamente diferentes foram identificados no dendrograma a partir da estimativa do valor mínimo de similaridade acima do qual os acessos são semelhantes. O valor máximo de similaridade significativo $\left(\mathrm{S}_{\mathrm{gm}}\right)$ foi estimado pelo Teste de $\mathrm{t}$, ao nível de $1 \%$ de probabilidade:

$$
S_{g m}=1-\left(t \times \bar{S}_{S_{i j}}\right)
$$

Em que:

$\mathrm{t}=\mathrm{o}$ valor tabelado de $\mathrm{t}$ com $\mathrm{n}-2$ graus de liberdade;

$\bar{S}_{S_{i j}}=$ erro médio das comparações consideradas no dendrograma.

\section{RESULTADOS E DISCUSSÃO}

Foram amplificados 279 fragmentos de DNA, sendo 194 polimórficos e 85 monomórficos, utilizando 80 primers de RAPD. Os genótipos agruparam-se em dois grupos bem distintos. O primeiro foi constituído pelas cultivares nobres e o segundo, pelas seminobres.

Al-Zahim et al. (1997), estudando 27 acessos das espécies de alho de diferentes países, sendo 11 materiais de Allium sativum var. sativum, 11 de $A$. sativum var. ophioscorodon e 5 de A. longicuspis, utilizando 25 primers, encontram 292 bandas, sendo 63 polimórficas, que foram utilizadas na geração do dendrograma. Segundo os autores, os acessos de Allium sativum var. sativum foram agrupados em um mesmo grupo, sendo as espécies A. sativum var. ophioscorodon e A. longicuspis Regel agrupadas, por RAPD, em um segundo grupo bem distinto do primeiro.

Bradley et al. (1996), estudando 20 cultivares de alho-australiano (Allium sativum) por RAPD, com 5 primers, encontraram 65 bandas polimórficas, utilizando 5 primers, os materiais formaram 2 grupos, com uma taxa média de similaridade na ordem de 58 a 97\%, indicando alto nível de variação genética. 
Observou-se um polimorfismo diferenciado nos trabalhos acima citados e também na quantidade de primer utilizado para o agrupamento das cultivares por RAPD. Segundo Santos (1994), a utilização de 100 a 200 fragmentos polimórficos dos dados para a análise de RAPD promove a confiabilidade dos resultados obtidos. Entretanto, Colombo et al. (1998) ressaltam que 10 a 30 primers, gerando de 50 a 100 bandas polimórficas, são suficientes para estimar relações genéticas dentro das espécies e entre elas.

No presente estudo, a análise de "bootstrap", realizada pelo programa GQMOL, mostrou que o emprego de 60 bandas polimórficas seria suficiente para gerar confiabiliadade na análise da diversidade genética das 12 variedades de A. sativum. Com 100 bandas polimórficas, houve $99,08 \%$ de correlação e o desvio-padrão apresentava-se próximo de zero $(0,005109)$. Observa-se que a partir desse valor a curva de correlação e o desvio-padrão não sofreram alterações com o incremento de 94 bandas restantes. Isso forneceu segurança e confiabilidade dos resultados obtidos neste estudo para divergência genética utilizando marcadores RAPD.

\section{Matriz de distâncias genética, erro estimado e similaridade genética}

A matriz das distâncias genéticas (Tabela 1) fornece a porcentagem de similaridade entre todas as doze cultivares de alho analisadas; com isso, foi possível construir uma figura gráfica ou dendrograma (Figura 2), que facilita a observação da relação entre as cultivares e permite analisar os indivíduos e suas semelhanças.

A análise de divergência genética, feita com base nas 194 bandas polimórficas selecionadas, indicou, para o grupo nobre, que as cultivares Contestado 12 e Quitéria 595 são mais próximas entre si, com valor de Jaccard igual a 0,855. A cultivar Roxo Pérola de Caçador é mais distante geneticamente em relação à cultivar Caçador 30, com um valor médio de Jaccard igual a 0,452. Para o grupo das cultivares seminobres, observou-se que as cultivares Amarante e Gigante Curitibanos são as mais próximas entre si (índice de Jaccard $=0,860$ ) e a cultivar Cateto Roxo mostrou-se mais distante geneticamente em relação à cultivar Gravatá (índice de Jaccard $=0,429$ ).

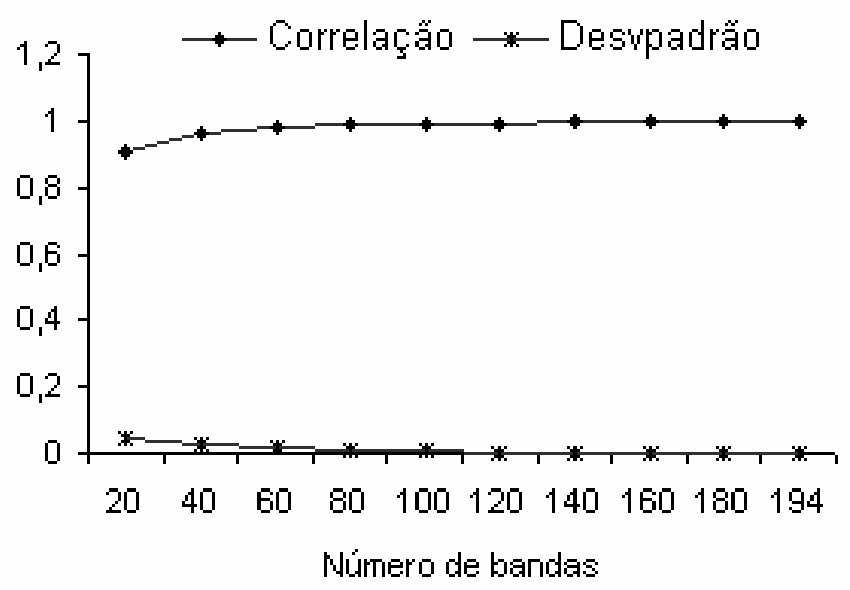

FIGURA 1 - Análises de "bootstrap" para a estimativa das distâncias genéticas entre doze cultivares de alho. 
Diversidade genética de cultivares de alho (Allium sativum L.) por meio de...

TABELA 1 - Matriz de distâncias genéticas entre as doze cultivares de alho analisadas.

\begin{tabular}{|c|c|c|c|c|c|c|c|c|c|c|c|c|}
\hline & Chonan & $\begin{array}{c}\text { R.P. } \\
\text { Caçador }\end{array}$ & $\begin{array}{l}\text { Gig. } \\
\text { Roxo }\end{array}$ & $\begin{array}{c}\text { Gig. } \\
\text { Curitibanos }\end{array}$ & $\begin{array}{l}\text { Gig. } \\
\text { Roxão }\end{array}$ & Amarante & $\begin{array}{c}\text { Cateto } \\
\text { Roxo }\end{array}$ & $\begin{array}{c}\text { Caçador } \\
\mathbf{3 0}\end{array}$ & $\begin{array}{c}\text { Quitéria } \\
595\end{array}$ & $\begin{array}{c}\text { Contestado } \\
12\end{array}$ & $\begin{array}{c}\text { Caçador } \\
40\end{array}$ & Gravatá \\
\hline \multicolumn{13}{|l|}{ Chonan } \\
\hline R. P. Caçador & 0,637 & & & & & & & & & & & \\
\hline Gig. Roxo & 0,282 & 0,299 & & & & & & & & & & \\
\hline Gig. Curitibanos & 0,270 & 0,287 & 0,837 & & & & & & & & & \\
\hline Gig. Roxão & 0,284 & 0,293 & 0,690 & 0,728 & & & & & & & & \\
\hline Amarante & 0,261 & 0,245 & 0,760 & 0,860 & 0,750 & & & & & & & \\
\hline Cateto Roxo & 0,253 & 0,290 & 0,542 & 0,538 & 0,641 & 0,534 & & & & & & \\
\hline Caçador 30 & 0,467 & 0,452 & 0,375 & 0,371 & 0,313 & 0,395 & 0,293 & & & & & \\
\hline Quitéria 595 & 0,550 & 0,584 & 0,379 & 0,375 & 0,350 & 0,348 & 0,307 & 0,646 & & & & \\
\hline Contestado 12 & 0,569 & 0,555 & 0,385 & 0,381 & 0,323 & 0,379 & 0,279 & 0,654 & 0,855 & & & \\
\hline Caçador 40 & 0,571 & 0,525 & 0,414 & 0,411 & 0,347 & 0,408 & 0,307 & 0,650 & 0,726 & 0,800 & & \\
\hline Gravatá & 0,335 & 0,312 & 0,603 & 0,589 & 0,521 & 0,573 & 0,429 & 0,425 & 0,410 & 0,435 & 0,500 & \\
\hline
\end{tabular}

Cruz (1990) afirma que a análise de agrupamento tem como objetivo dividir um grupo original de observações em vários grupos homogêneos, segundo algum critério de similaridade ou dissimilaridade. Dias (1998) informa que o agrupamento é importante para sumarizar a informação contida na matriz de distâncias. De fato, pode-se observar pelo dendrograma o agrupamento das 12 cultivares de alho em dois grupos bem distintos, ou seja, houve relação entre a região de cultivo das cultivares e a formação dos grupos. A cultivar Gigante Curitibanos, que é cultivada no sul do Brasil, foi originada em Minas Gerais, e pelo dendrograma, essa cultivar foi agrupada conjuntamente com as cultivares seminobres.

O dendrograma gerado pela análise estatística (Figura 2) possibilitou a interpretação dos resultados obtidos pela técnica de RAPD com as vantagens de mostrar o grau de similaridade e possibilitar o agrupamento das 12 cultivares de $A$. sativum.

O primeiro grupo foi formado pelas cultivares nobres (Chonan, Roxo Pérola de Caçador, Caçador 30, Quitéria 595, Contestado 12, Caçador 40). Essas cultivares têm em comum a necessidade de serem vernalizadas antes do plantio nas Regiões Sudeste, Centro-Oeste e em alguns microclimas de baixas temperaturas na Região Nordeste. O segundo grupo foi formado pelas cultivares seminobres (Gigante Roxo, Gigante Roxão, Amarante, Cateto Roxo, Gravatá e Gigante Curitibanos) ou que não precisam de vernalização para a formação do bulbo.
Foram obtidas 66 estimativas de similaridade genética entre as 12 cultivares de alho com estimativa média de $47 \%$ e amplitude de $24 \%$ a $86 \%$. As cultivares nobres formaram um grupo com $57,1 \%$ de similaridade e as cultivares seminobres, um grupo com $54,2 \%$ de similaridade.

As cultivares Chonan e Caçador foram similares em 63,7\%. Em estudos conduzidos por Siqueira et al. (1985), essas cultivares foram reunidas no mesmo grupo com relação aos padrões isoenzimáticos de álcool desidrogenase, esterase, peroxidase e fosofoglucoisomerase. Em outro estudo, Augustin e Garcia (1993) observaram que as cultivares Chonan e Caçador são muito semelhantes em formato de bulbo, número de bulbilhos e apresentam resistência moderada à ferrugem.

Augustin e Garcia (1993), avaliando 35 clones de alho nacionais e introduzidos do Uruguai e Argentina por análise enzimática e de proteínas, obtiveram coeficiente de similaridade variando de $0,71 \%$ a $0,96 \%$, mostrando haver elevado grau de semelhança entre as cultivares estudadas.

Quando se obtém alta diversidade genética entre espécies vegetais, pode-se concluir que esse material encontra-se num estádio de pouca domesticação e, dessa forma, uma cultura pouco manipulada pode ter seu polimorfismo facilmente acessado, pois, para isso, é necessário um pequeno número de primers (XAVIER, 2001). 


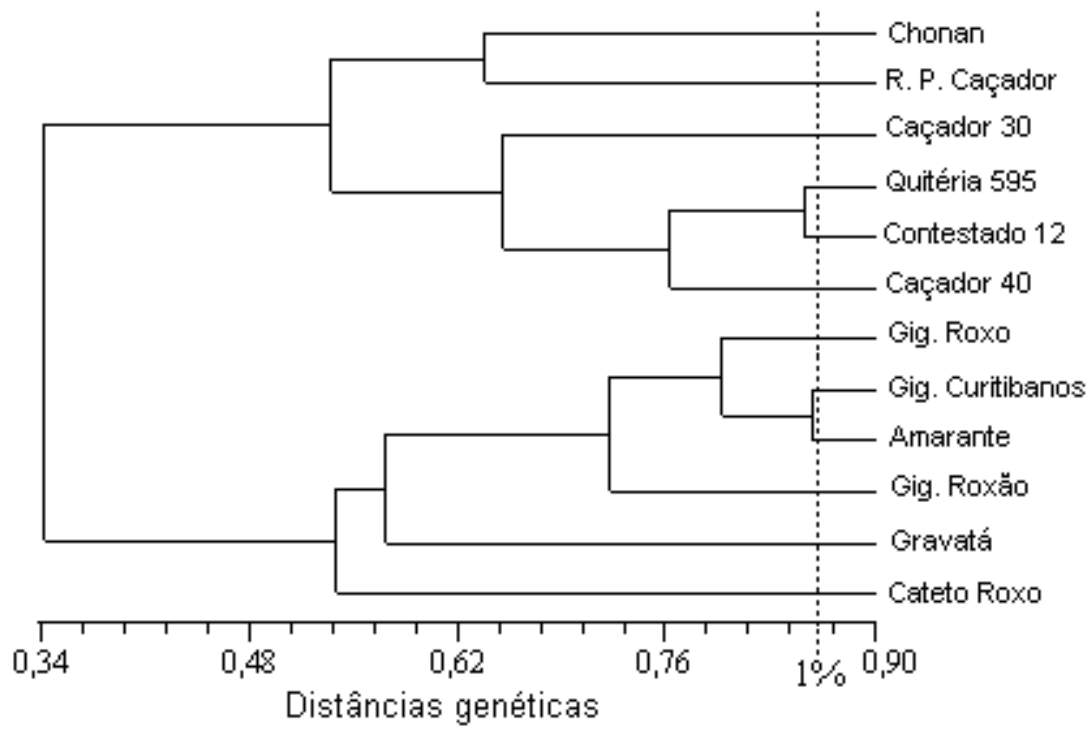

FIGURA 2 - Dendrograma das distâncias genéticas entre as 12 cultivares de alho, geradas pelo programa NTSYSpc $2.02 \mathrm{k}$. A linha de corte ao nível de $1 \%$ de probabilidade representa o valor máximo significativo $\left(\mathrm{S}_{\mathrm{gm}}\right)$, acima da qual as cultivares são consideradas semelhantes $(0,88)$.

\section{CONCLUSÕES}

Pelos resultados apresentados, pode-se concluir que:

a) As cultivares são geneticamente distintas entre si, apesar das semelhanças fenotípicas.

b) A técnica de RAPD é útil para caracterizar geneticamente cultivares de alho (Allium sativum L.), considerando a qualidade da amplificação e o nível do polimorfismo entre as cultivares.

c) A análise da estabilidade do coeficiente de similaridade genética por meio de bootstrap mostrou que 194 bandas polimórficas foram suficientes para uma estimativa estável da divergência genética entre as cultivares de alho.

\section{AGRADECIMENTOS}

Ao Núcleo de Biologia Aplicada da EMBRAPA CNPMS em Sete Lagoas-MG, na pessoa do Dr. Edílson Paiva.

\section{REFERÊNCIAS BIBLIOGRÁFICAS}

AL-ZAHIM, M.; NEWBURY, H. J.; FORD-LLOYD, B. V. Classification of genetics variation in garlic (Allium sativum L.) revealed by RAPD. HortScience, Alexandria, v. 32, n. 6, p. 1102-1104, Oct. 1997.
AUGUSTIN, E.; GARCIA, A. Classificação isoenzimática, morfológica e agronômica de genótipos de alho. Horticultura Brasileira, Brasília, v. 11, n. 1, p. 10-13, maio 1993.

BRADLEY, K. F.; RIEGER, M. A.; COLLINS, G. C. Classification of Australian garlic cultivars by DNA fingerprinting. Australia Journal of Experimental Agriculture, Melbourne, v. 36, p. 613-618, 1996.

COLOMBO, C.; SECOND, G.; VALLE, T. L.; CHARRIER, A. Genetic diversity characterization of cassava culivars (Manihot esculenta Crantz) RAPD market. Genetics and Molecular Biology, Ribeirão Preto, v. 21, n. 1, p. 105-113, 1998.

CRUZ, C. D. Aplicativo de algumas técnicas multivaridas no melhoramento de plantas. 1990. 188 f. Tese (Doutorado em Genética e Melhoramento de Plantas) - Escola Superior de Agricultura Luis de Queiroz, Piracicaba, 1990.

CRUZ, C. D. Programa GQMOL: análise de dados moleculares e associação com caracteres quantitativos. Viçosa: UFV, 1999. Software.

DIAS, L. A. S. Análises multidimensionais. In: ALFENAS, A. C. (Ed.). Eletroforese de isoenzimas e 
proteínas afins: fundamentos e aplicações em plantas e microorganismos. Viçosa: UFV, 1998. p. 401-475.

FERREIRA, M. E.; GRATTAPAGLIA, D. Introdução ao uso de marcadores moleculares em análise genética. 3. ed. Brasília: EMBRAPA/CENARGEN, 1998. $220 \mathrm{p}$.

FILGUEIRA, F. A. R. Manual de olericultura: cultura e comercialização de hortaliças. 2. ed. São Paulo: Agronômica Ceres, 2000. 357 p.

LIMA, P. S. G. Divergência genética e efeito do nitrogênio total no crescimento in vitro de ipeca [Pyschotria ipecacuanha (Brot.) Stokes]. 2001. 83 p. Dissertação (Mestrado Genética e Melhoramento de Plantas) - Universidade Federal de Lavras, Lavras, 2001.

ROHLF, F. J. Numerical taxonomy and multivariate analysis system. Version 2.02. New York: [s.n.], 1992. Software.

SAKIYAMA, N. S. Marcadores moleculares e as hortaliças. Horticultura Brasileira, Brasília, v. 11, n. 2, p. 204-206, nov. 1993.
SANTOS, J. B. Emprego de marcadores moleculares no melhoramento de plantas. Horticultura Brasileira, Brasília, v. 12, n. 2, p. 282-286, 1994.

SIQUEIRA, W. J.; MEDINA FILHO, H. P.; LISBÃO, R. S.; FORNASIER, J. B. Caracterização isoenzimática e morfológica de clones e introduções de alho. Bragantia, Campinas, v. 44, n. 1, p. 357-374, 1985.

SKROCH, P.; TIVANG, J.; NIENHUS, J. Analysis of genetic relationships using RAPD marker data. In: APPLICATIONS OF RAPD TECHNOLOGY TO PLANT BREEDING, 1992, Minneapolis. Proceedings... Minneapolis: Crop Science Society of America, 1992. p. 26-30.

SOUZA, R. J. de; SATURNINO, H. M.; MASCARENHAS, M. H. T.; LARA, J. F. R. Caracteres morfológicos de 17 cultivares de alho (Allium sativum L.) Prudente de Morais (MG)-1978. In: Projeto olericultura. Belo Horizonte: [s.n.], 1981. p. 29-33. (Relatório 77/78).

XAVIER, K. G. Divergência genética em clones de Eucalyptus avaliada por marcadores RAPD, e variações nas propriedades da madeira. 2001. 107 p. Dissertação (Mestrado Engenharia Florestal) Universidade Federal de Lavras, Lavras, 2001. 